609 - Jozjasz ginie pod Megiddo w starciu z faraonem Neko

597 - Nabuchodonozor zdobywa Jerozolimę i uprowadza do niewoli króla Jojakina (16 marca)

586 (lub 587) - zdobycie (lipiec), zburzenie Jerozolimy, spalenie Świątyni (sierpień), drugie przesiedlenie, niewola babilońska ${ }^{11}$.

Kraków-Tarnów

KS. TADEUSZ BRZEGOWY

\title{
Ks. Norbert Mendecki
}

\section{ZNACZENIE ODKRYCIA GENIZY KAIRSKIEJ}

Żydowskim zwyczajem rękopisy i przedmioty kultyczne, co do których miano pewne zastrzeżenia, przechowywano w specjalnym pomieszczeniu synagogalnym, by po jakimś czasie ułożyć je w poświeconej ziemi. W ten sposób zabezpieczano owe manuskrypty i przedmioty kultyczne przed znieważeniem, gdyż te zawierały święte imię Boga Jahwe ${ }^{1}$.

Wyraz „geniza" (perskie genez odpowiada aramejskiemu genaz/ginza) występuje w Starym Testamencie w liczbie mnogiej u Ez 27, 24 w znaczeniu „tkaniny"2 i Est 3, 9; 4, 7 w znaczeniu ,skarbiec

${ }^{11}$ Zob. C. S ched l, Nochmals das Jahr der Zerstoerung Jerusalems, 587 oder 586 v. Chr., ZAW 74 (1962) 209-213; E. Vogt, Bemerkungen ueber das Jahr der Eroberung Jerusalems, „Biblica” 56 (1975) 223-230. Biblia Tysiaclecia (wyd. 3, s. 4 tablicy chronologicznej) datując zdobycie Jerozolimy na $587 / 586$ sugeruje, że miało to miejsce na przełomie lat 587 i 586. Otóż „miesiąc piąty” $2 \mathrm{Krl} 25,8 \mathrm{w}$ żadnym z systemów liczenia nowe roku (wiosenny lub jesienny hebrajski czy zimowy gregoriański) nie przypadał na przełomie lat.

${ }^{1}$ Por. A.M. H a b e r m a n n, Genizah, Encyclopaedia Judaica, VII, 404-407 , szczeg. 404.

${ }^{2}$ W. Zi m me rli, Ezechiel (Biblischer Kommentar. Altes Testament XIII/2), Neukirchen - Vluyn ${ }^{2} 1979,625$. 
królewski”3 1 Krn 28, 11 mówi też o skarbcu (ganzak). W literaturze talmudycznej spotykamy często czasownik ganaz w znaczeniu „przechować”, „ukryć”, „schować”. Od tego czasownika pochodzi rzeczownik genizah na oznaczenie miejsca przechowania, czy ukrycia, pierwotnie $\mathrm{z}$ wyrazem bet (bet genizah), w czasach nowożytnych występując samodzielnie (genizah). W czasach powstania miszny i talmudu istnial zwyczaj przechowywania kultycznych rekwizytów ${ }^{5}$ (przedmioty, które nie nadawały się do użytku kultycznego albo zostały stamtąd wycofane) w przeznaczonym do tego miejscu ${ }^{6}$. Niekiedy owe rekwizyty kultyczne po prostu zakopywano do ziemi ${ }^{7}$. Ów zwyczaj pielęgnowali qumrańczycy. Świadczą o tym kości zwierząt, które zostały ze czcią przez wspólnotę qumrańską pogrzebane ${ }^{8}$. W „genizie” przechowywano również zwoje Pisma św., co do których miano pewne zastrzeżenia. Dla przykładu, zwoje sporządzone przez osobę nieżydowską (bGittin 45b) albo zwoje zawierające więcej aniżeli trzy błędy w każdej kolumnie (bMenahot 29b). Także zwoje, w których imię Boże z przepychem było ozdobione (np. pokryte złotem) umieszczano w „genizie” (bSabbat 103b). Podobny los spotykał tefillin, filakterie, których teksty nie były w prawidłowej kolejności zapisane (Mekilta $\mathrm{Wj}$ 13, 16). Owe przedmioty przechowywano $\mathrm{w}$ specjalnym pomieszczeniu, najczęściej w jakimś schowku synagogalnym, by po jakimś czasie uroczyście zakopać je do ziemi. Za podobnym zwyczajem przemawia 1 Mch 4, 46: „A kamienie (ołtarza całopalenia) złożyli na oznaczonym miejscu na świątynnej górze, na tak długo, aż ukaże się prorok i nimi rozporządzi”. 2 Mch 2, 4nn mówi o przechowaniu i ponownym znalezieniu namiotu i arki

${ }^{3}$ G. Ge rle ma n, Esther (Biblischer Kommentar. Altes Testament XXI), Neukirchen - Vluyn 1973, 88, 95, 101.

${ }^{4}$ Por. J. M a i e r, Bedeutung und Erforschung der Kairoer "Geniza”, "Jahrbuch für Antike und Christentum" 13 (1970), 48-61, szczeg. 49. według niego ganaz przybrało uboczne znaczenie - „wycofać się ze sfery życia publicznego".

${ }^{5} \mathrm{O}$ tym zwyczaju nic nie wspomina Biblia.

${ }^{6}$ Trudno rozstrzygnąć, czy grota poza murami Jerozolimy, niedawno odkryta, z około 1300 naczyniami glinianymi, pochodzącymi z okresu żelaza, stanowi pewien rodzaj "genizy", por. K. Ke ny o n, Excavations in Jerusalem, PEQ 100 (1968), 97-109; G.R.H. W righ t, The „Granary” at Shechem and the underlying storage pits, ZAW 82 (1970), 275-278.

${ }^{7}$ Por. inne znaczenie ganaz w tSota XII, 5 - „usunięcie się, zniknięcie sprzed oczu" (=wniebowzięcie Eliasza).

${ }^{8} \mathrm{~J}$. M a i e r, dz. cyt., 49 uważa, że święte zwoje, ukryte w grotach qumrańskich wskazują między innymi na ten zwyczaj. 
przymierza, 2 Mch 1, 19 o ogniu z ołtarza. Owe motywy przejęła literatura talmudyczna i szeroko rozpracowała.

Literatura talmudyczna zna też zwyczaj przechowywania w specjalnym pomieszczeniu przedmiotów wycofanych $\mathrm{z}$ kultu, by te uchronić przed profanacją. Dla przykładu nóż kultyczny (mMiddot IV, $7 \mathrm{i}$ inne), kamienie świątynne (tMegillah III, 5) itp. W czasach, kiedy świątynia jerozolimska leżała w gruzach, ograniczono ów zwyczaj do ksiąg świętych i przedmiotów chroniących owe księgi, gdyż według tradycji talmudycznej teksty zawierające imię Boże traktowano na równi z przedmiotami kultycznymi. Zwyczaj ten sięga czasów talmudycznych. bMegillah $26 \mathrm{~b}$ opisuje ciekawy sposób czczenia zmarłych uczonych w Piśmie, dla których prześcieradło, którym owijano zmarłego, sporządzano z okryć zwojów świętych. Stąd najprawdopodobniej wziął tutaj początek późniejszy zwyczaj grzebania nie tylko okryć zwojów świętych ale też samych zwojów ${ }^{9}$. Jeszcze inne (przenośne) znaczenie przyjął czasownik ganaz. Wycofywanie pewnych przedmiotów z użytku kultycznego związane było $\mathrm{z}$ pojęciem kanoniczności, a tym samym dopuszczalności do kultu owych przedmiotów. Według mPesahim IV, 9 i bBerakot 10b król Ezechiasz kazał „ukryć” podręcznik medycyny, co równało się z zakazem używania tego podręcznika. Podobnie Targum Księgi Hioba zamurowano. W czasie dyskusji rabinackich nad kanonicznością ksiąg świętych, odsyłano niektóre księgi do „genizy”, ponieważ podważano ich autentyczność. Taki los spotkał Księgę Ezechiela, Przysłów, Koheleta, Pieśni nad Pieśniami i inne.

W końcu ganaz znaczy „utracić”. W takim znaczeniu używa bPesahim 62a, mówiąc o przytępieniu wzroku uczonych w Piśmie od czasu, kiedy „Księga Genealogii” zaginęła (dosłownie „została ukryta") $)^{10}$.

Również kairska synagoga posiadała owe pomieszczenie na rękopisy $^{11}$, choć w tym wypadku zapomniano tutaj najprawdopodobniej o grzebaniu starych pism. Dzięki temu zachowały się cenne ma-

${ }^{9}$ A. Hiram, Antike Synagogen und altchristliche Kirchenbauten, „Wiener Jahrbuch für Kunstgeschichte” 19 (1962), 7-63, szczeg. 12 uważa, że pod absydą starożytnej synagogi w Bet Alfa znajdujące się wgłębienie (jama) służyło jako „geniza".

${ }^{10}$ Por. też bSotah 49b - od czasów śmierci Rabbi Eleazara, Tora została „ukryta" (= straciła wartość).

${ }^{11}$ Chodzi tutaj o synagogę Ezdrasza w Starym Kairze (Fustat) wybudowaną w VII wieku w miejsce kościoła koptyjskiego, I. E l b oge n, Jüdisches Lexikon, II Berlin ${ }^{2} 1968,1014-1015$, szczeg. 1014. 
nuskrypty, mające przeogromne znaczenie w badaniu naukowym. Odkrycia genizy kairskiej dokonał profesor uniwersytetu w Cambridge, Salomon Schechter. W r. 1896 otrzymał on rękopis, który zidentyfikował jako hebrajski Jezus Syrach ${ }^{12}$, Od tego momentu zaczęło się systematyczne badanie naukowe kairskiej genizy. Jeszcze w tym samym roku 1896 udał się profesor Schechter do Kairu i po otrzymaniu zezwolenia od pełnomocnika synagogi zebrał około 60 walizek manuskryptów do Cambridge. Zawartość owa liczyła około 100000 fragmentów. Prawie drugie tyle fragmentów znajduje się w różnych bibliotekach, takich jak: Nowy York, Oksford, Londyn, Paryż, Frankfurt i w zbiorach prywatnych ${ }^{13}$.

Skąd wzięła się taka ogromna liczba fragmentów, skoro rzekomo zapomniano o strychu genizy synagogalnej? Trzeba tutaj najpierw zauważyć, że o genizie kairskiej nie zapomniano zupełnie. Niejaki Szymon „od pieniędzy” szukał tutaj w r. 1752 cennych rękopisów. Zbieracz (i zarazem fałszerz) Abraham Firkowitsch nabył teksty, które z wielkim prawdopodobieństwem uchodzą za autentyczne z kairskiej genizy. W r. 1864 niejaki Jakub Saphir był właśnie na strychu synagogi (czyli w genizie), ale wśród rękopisów nie znalazł nic godnego uwagi ${ }^{14}$. Jeżeli zaś chodzi o liczbę fragmentów (oszacowano je na około 100000 , rozproszonych po różnych bibliotekach i zbiorach prywatnych), przypuszcza się, że nie wszystkie pochodzą ze strychu synagogi w Starym Kairze. Wiele z nich odkopali handlarze na cmentarzu Basatin. Do roku 1970 zbadano tylko jedną trzecią znalezionych rękopisów, dlatego trudno ocenić w całości plon znaleziska. Dotychczasowe przebadane fragmenty pochodzą od IX aż do XVII wieku. Najstarszy dokument tzw. ketubbah (kontrakt ślubny) datuje się na rok 870 po $\mathrm{Chr}$., według niektórych uczonych nawet na rok 750 po $\mathrm{Chr}^{15}$

Największe zainteresowanie w świecie naukowców przyniósł hebrajski tekst Księgi Syracha. Jak już wyżej wspomniano w r. 1896 Salomon Schechter zidentyfikował dostarczony mu tekst, jako fragment z Księgi Syracha. Wkrótce opublikowano jeszcze inne fragmenty tejże Księgi, które umożliwiły pełne wydanie hebrajskiego

${ }^{12}$ Fragmenty tego rękopisu dostarczyły Profesorowi Schechterowi dwie zbieraczki A.S. Lewis i M.D. Gibson, por. J. M a i e r, dz. cyt., 51. 552.

${ }^{13}$ H. H a a g, Geniza, Bibel-Lexikon, Einsiedeln ${ }^{2} 1968$, 552-553, szczeg.

${ }_{14}^{14}$ A.M. $\mathrm{H}$ a b e r m a n n, dz. cyt., 405.

${ }^{15}$ Por. wyjątkowe stanowisko J.L. Teichera, datującego ów fragment na rok 1050 po n. Chr., J. M a i e r, dz. cyt., 52. 
tekstu Syracha. Powstało więc pytanie, czy hebrajski tekst Księgi Syracha jest autentyczny, czy chodzi raczej tutaj o hebrajskie tłumaczenie z języka greckiego? W r. 1964 odkryto w Masadzie hebrajski (niepełny) zwój Księgi Syracha. Porównano teraz obydwa teksty, (z kairskiej genizy z tekstem z Masady) i uczeni doszli do wniosku, że chodzi tutaj o autentyczny hebrajski tekst Księgi Syracha, a nie o tłumaczenie hebrajskie $\mathrm{z}$ języka greckiego ${ }^{16}$.

Jakie jeszcze inne znaczenie ma geniza kairska dla judaistyki? Teksty hebrajskie ${ }^{17}$, aramejskie (targumy) ${ }^{18}$, greckie (tłumaczenie Aquili) ${ }^{19}$, palestyńsko-syryjskie mają ogromne znaczenie dla filologów tychże języków ${ }^{20}$.

Salomon Schechter znalazł w genizie kairskiej tzw. „pismo damasceńskie", które opublikował fragmentarycznie w r. 1910. Owo pismo datuje się na czasy II w. przed Chr. - I w. po Chr. Fragmenty znaleziono również w szóstej grocie w Qumran ${ }^{21}$.

Wielkie znaczenie ma także odkrycie w genizie kairskiej dla badaczy języka i literatury talmudycznej. Na tym polu poczyniono dotychczas bardzo małe postępy. Brakuje jak dotąd, nowego wydania miszny, tosefty, talmudu babilońskiego i jerozolimskiego oraz midraszów w oparciu o odkryte teksty.

Oprócz literatury talmudycznej znaleziono w genizie tzw. „responsen” (odpowiedzi). Żydzi rozproszeni po całym świecie kierowali pytania w sprawach kultu $\mathrm{i}$ religii do sławnych uczonych-

${ }^{16}$ H.P. R üge r, Text und Textform im hebräischen Sirach. Untersuchungen zur Textgeschichte und Textkritik der hebräischen Sirachfragmente aus der Kairoer Geniza, Beihefte zur ZAW, Berlin 1970, passim, szczeg. 1-11.

${ }^{17} \mathrm{~S}$. Yeivin, A Babylonian fragment of the Bible in the abbreviated system, "Textus” 2 (1962), 120-139; E.J. R e ve ll, A new Biblical fragment with Palestinian vocalisation, „Textus” 7 (1969), 59-75; H.P. K r ü ge r, Ein neues Genesisfragment mit komplizierter babylonischer Punktation aus der Kairoer Geniza, VT 13 (1963), 235-237; tenże, Ein neues Fragment des Richterbuches mit babylonischer Punktation, ZAW 75 (1963), 223-225.

18 Por. P.E. Kahle, Die Kairoer Genisa. Untersuchungen zur Geschichte des hebräischen Bibeltextes und seiner Übersetzungen, Berlin 1962, 203-218.

${ }^{19}$ Por. między innymi H.P. R üg e r, Vier Aquila-Glossen in einem hebräischen Proverbienfragment der Kairoer Geniza, ZNW 50 (1959), 275-277 .

${ }^{20}$ Por. między innymi W. B a a r s, A Palestinian Syriac text of the Book of Lamentations, VT 10 (1960), 225-227. 63.

${ }^{21}$ E. L o h s e, Die Texte aus Qumran, Darmstadt 1971, 63-107, szczeg. 
talmudystów, przede wszystkim w Babilonii. Odpowiedzi na te pytania nazywają się „responsen”22.

Odkrycia w genizie kairskiej dotyczą też liturgii i poezji synagogalnej. Na uwagę zasługuje modlitwa „Osiemnastu Błogosławieństw” opublikowana w r. 1898 przez Salomona Schechtera ${ }^{23}$ oraz modlitewnik sporządzony przez Rab Saadja Gaona (882-942). Na podstawie różnych dokumentów (dotyczących dla przykładu kontraktów handlowych, kontraktów małżeńskich a nawet tekstów dotyczących astrologii i medycyny itp.) oraz na podstawie prywatnych listów odtworzyć można historię Żydów z początków Średniowiecza, a nawet niektóre biografie, jak np. Saadjii Gaona czy Jehudy Hal$\operatorname{levi}^{24}$.

Już z tych pobieżnych informacji wynika, że odkrycia z genizy kairskiej mają ogromne znaczenie dla nauki. Na ostateczne podsumowanie jest tutaj jednak za wcześnie, ponieważ aż $2 / 3$ materiałów nie zostało jeszcze przebadanych ${ }^{25}$.

Wiedeń

KS. NORBERT MENDECKI

${ }^{22}$ Por. Sh. Ta l, Responsa, Encyclopedia Judaica, XIV, 83-95, szczeg. 84-85.

${ }^{23}$ S. S c h e c h t e r, Genizah specimens, JQR O.S. 10 (1898), 654-659.

${ }^{24}$ Por. też historie niejakiego Obadji, prozelity z Normandii, A. S c h ei b e r, Geniza Studies, Hildesheim 1981, 453-470.

${ }^{25} \mathrm{Na}$ temat znaczenia odkrycia genizy kairskiej zob. jeszcze J. C h mi el, Genisa - verborgenes Erbe. Die Kairoer Genisa und die Genisot der neuzeitlichen Synagogen, „Analecta Cracoviensia” 26/1994/169-172; tenże, Stulecie odkrycia hebrajskich rękopisów Księgi Syracha w genizie kairskiej, w: Światla Prawdy Bożej, pr. zb. ku czci Ks. Prof. Lecha Stachowiaka pod red. ks. E. Szewca, Łódź 1996, ss. 15-19; tenże, Język Księgi Syracha $w$ stulecie odkryć genizy kairskiej, w: Sprawozdania z posiedzeń Komisji Naukowych PAN Oddział w Krakowie, t. XI/1, Kraków 1997, ss. 39n. 